\title{
Problems and challenges for the Politics of Education before the change of prominence experienced by educational actors
}

\author{
Juan Manuel Fernández-Soria* \\ Dpto. Educación Comparada e Historia de la Educación, Universidad de Valencia, Spain \\ \{juan.m.fernandez@uv.es\}
}

Received on 17 April 2013; revised on 18 April 2013; accepted on 13 May 2013; published on 15 July 2013

DOI: 10.7821/naer.2.2.63-71

\begin{abstract}
This paper deals with some of the problems that the Politics of Education has to face both as a subject and as a government action. Based above all on the literature appeared in specialized journals during the last five years, our attention is firstly focused on the concern for using an active methodology in the teaching of this subject which places students at the center of the teachinglearning process with the aim of encouraging their interest in its contents and inducing them to acquire civic competences. Secondly, the new but already deeply-rooted neoliberal conception of education is used to describe some of its policies, such as accountability, assessment and free choice of school. Our study finally stresses the change of prominence experienced by educational actors and calls researchers and teaching staff to face such challenges from an understanding of politics as a transforming action that seeks equality and social cohesion.
\end{abstract}

KEYWORDS: POLITICS OF EDUCATION, ACCOUNTABILITY, GOVERNANCE, EVALUATION, EDUCATIONAL CHOICE

\section{INTRODUCTION}

If the concept of 'problem' is understood as the difficulty to achieve an aim, then the Politics of Education (hereinafter referred to as $\mathrm{PE}$ ) is problematic both as a discipline and as a government idea and action. It goes without saying that PE problems are not confined to those which will be treated here; it may even happen that some people do not regard them as problems but rather as a solution to the difficulties that the education of our time is going through. After all, the notion of Politics, and consequently that of PE, is related to the conception that each individual has of life and of the world. Therefore, before coming to the core of this study, it is worth clarifying what is understood by Politics here. That will become particularly relevant to contextualize the second part of this paper. Fernández-Soria (2012, pp. 112-113) claimed in a recent work that good politics has as its main aim to achieve transforming projects for the benefit of the common good, oriented to consolidate a desirable society and reality rooted in democracy. Taking as a reference Hannah Arendt's thoughts, he

*To whom correspondence should be addressed

Universidad de Valencia.

Facultad de Filosofía y Ciencias de la Educación.

Departamento de Educación Comparada e Historia de la Educación.

Avda. Blasco Ibáñez, 30.

46010-Valencia.

Spain. also chose to understand good politics as the action and the word which - pursuing that transforming goal- is preferably exerted in public spaces (the place of politics), as opposed to private spaces (the territories par excellence of economic activity). Domination corresponds to the private space, and to the economic sphere; instead, what prevails in the public space is "the realm of freedom (in the sense given to it by the ancient thinkers), a freedom which is expressed in an equal right for every citizen to be directly involved in public affairs" (Ferry, 1998, pp. 13-14).

PE problems constantly attract the attention of experts, though from different approaches (Puelles, 2006; Jones, 2013). Many of these problems still remain unsolved despite having been detected years ago, and they are actually acquiring more relevance in current debates, thus stressing even more the uncertainties associated with PE. The present paper will show some of those problems, which have repeatedly appeared in documents and, above all, in specialized journals during the last five years. The first part of the text deals with issues referring to political science and, consequently, to $\mathrm{PE}$ as a subject, focusing on concerns which affect its epistemology, the teaching-learning process and its important role in enabling civic commitment. In this sense, the paper seeks to encourage scholars to reflect on the challenges faced by PE as a subject. The second part of our study highlights a number of problems that affect PE as a government idea and action: accountability; school governance; assessment; the privatization of public education; and schooling. In this respect, the study tries to show that the pressure exerted by the neoliberal ideology is making PE go through a decisive change in the traditional -and until recently also regarded as progressive- prominence of some educational actors, especially of the State, gradually relegated by the market. And most strikingly, an attempt is being made to justify this change of main actors arguing that society demands it; it is the discourse of social needs.

\section{PROBLEMS AND CHALLENGES FOR THE POLITICS OF EDUCATION AS A SUBJECT}

Even specialized media have revealed some interest in the teaching and learning of political science, and to a much lesser extent of PE, although the solution provided for the former might as well be extrapolated to the latter. Issues related to the methodology, conceptualization and epistemology of the discipline monopolize that interest.

There is usually a questioning of the conventional uses in favor of active methods which can involve the student in the subject without sacrificing the necessary knowledge. These 
procedures require the involvement of students, a teacher playing the role of facilitator in such a process, and the utilization of resources that improve the motivation and attitude towards politics, that help understand the facts and decisions related to it and increase the degree of civic commitment inside and outside classrooms. These resources can be the cinema (Bostock, 2011), the press (Huerta \& Jozwiak, 2008) or up-todate texts that the student can better identify with (Teten, 2010). The research on the use of student-centered learning models has shown its utility as a pedagogical tool in political science teaching; problem-based learning is particularly well valued in student satisfaction surveys (Williamson \& Gregory, 2010). Other research works analyze the impact of simulations on learning and on the growth of students' civic competence, this flair being understood as the individual ability to give sense to vast amounts of political information, to work with others (even with those who do not share our own ideas) and to develop effective strategies for political action. Bernstein studied the impact of simulations and found that, with some limitations, students leave the classroom with greater confidence in the management of tasks which require active participation, that confidence having more to do with the skills achieved than with the knowledge acquired. He finishes stating that his results "provide solid evidence that we should reconsider how we teach students" (Bernstein 2008, p. 1). However, the degree of success associated with the achievements obtained in the simulation of learning situations is sometimes greater among students who assume a power or leadership role in that simulation (Baranowski \& Weir, 2010). In any case, practical and experiential learning stimulates students' interest in political issues and endows them with relevant civic competences which go beyond the local context. Brunell (2013) measured students' knowledge and competence levels before and after their participation in experiential learning projects, confirming an increase of their interest, knowledge and active involvement in civic-political matters of global importance. The conviction exists that teaching politics through a "placement learning pedagogy" not only enriches its understanding but also favors its study. Curtis and Blair (2010) proved that most of the students who went through this pedagogy feel more respect for political activity in general and, particularly, take greater interest in local politics.

The uneasiness over the political apathy of citizens in general and young people and students in particular clearly lies behind the interest in political science teaching. Thus, Ferman (2012, pp. 232-233) identified a 'profane troika' -"relevance, negativity and the triumphant market"- which hinders the participation of young people, who cannot see the relevance that politics and government have in their lives and witness the thrust of market ideology with its rush to privatize and defend the individual. It all has deteriorated students' belief in politics, as a result of which they do not feel the need to acquire the skills and knowledge required for democratic participation. Nevertheless, our role as educators forces us to help them implement the willingness and civic capacity to become involved in the wellbeing of society, its institutions and its processes; hence the efforts made by numerous teachers to promote a critical spirit as well as reasonable political attitudes in their students. Unfortunately, the results have been rather modest sometimes, as shown, amongst others, by a research initiative where the implementation of a citizens' assembly model with a group of students seeking to break the political apathy only achieved a modest increase of their civic commitment level (Gershtenson, Rainey Jr. \& Rainey, 2010).

All the same, students need experiential learning -which symbolizes the link between education and society- in order to understand how politics works; and conversely, an adequate teaching of politics improves experience-based didactic activities. What is more: a good teaching of our discipline provides support for the basic pillars of civic education (Sloam, 2010). This is especially urgent at a time when the overabundance of information obtained through search engines on the Internet is changing the way to learn, replacing calm and careful reading with the instantaneous reception of uncritical pieces of information (Thornton, 2010).

Researchers and teachers can largely contribute to achieve this aim by removing the false barriers which often separate them when they can actually benefit each other. The former, as Sloam (2010) said, by clarifying concepts and issues that the latter, the teaching staff, need to enable their students to achieve a full understanding of politics and carry out its experiential learning successfully. In this sense, the often almost non-existent relationship that teachers maintain with their peers raises some concern as well. Hartlaub and Lancaster described after carrying out a nationwide survey how many teachers have absolutely no idea what other colleagues (even those belonging to the same department) do in their classrooms. This actually means that "the university classroom is simultaneously an intimate space and a distant environment" (Hartlaub \& Lancaster, 2008, p. 377). Departments prepare their syllabuses and pedagogical models every year with practically no knowledge of what is most often done in the profession; an attitude in which the personal characteristics of teachers become essential, while their previous experience as students and the institutional framework (number of students, etc.) are hardly significant.

Without a doubt, the connection between teachers is a must for many reasons, but it also becomes inescapable because of the conceptual and epistemological difficulties that are present in this specific subject. Paradoxically, political science is becoming increasingly conceptual and abstract, a feature which imposes the need for a certain degree of consensus on concept clarification which is necessary to teach and learn politics where the utilization of concepts precisely stands out as one of the most important obstacles. Not all concepts enjoy the agreement on their meaning that exists in the case of 'academic freedom,' for instance. Others, such as the concepts 'politics,' 'nation,' 'State' or 'democracy,' admit several adjectives and meanings. Laura B. Perry (2009) pointed out in this respect that, although there is coincidence on what the expression 'democratic schooling' stands for, there is no such coincidence on the meaning of the word 'democratic,' which leads her to establish a conceptual model for the analysis of PE in democratic societies that has as its basis the key concepts of equality, diversity, participation, choice and cohesion, thus facilitating $\mathrm{PE}$ comparison and analysis across different democratic societies. The lack of clarity and consensus as far as concepts are concerned may end up provoking situations in the classroom which are -to say the least- problematic. Thus, for example, the meaning of some concepts is sometimes negotiated in the classroom either because they lack a univocal use or meaning or because that negotiation helps involve the student in a participative class dynamics. The dilemma lies in deciding which of these two options is more convenient: a significant construction of concepts in the teaching-learning process; or an exposition of the meaning coined for those concepts. Expressed 
differently: instruction or personal construction of knowledge? As is well known, the answer to this question will affect knowledge assessment and programming. Jansson, Wendt and Ase (2013) studied this problem in relation to the concept 'Nation' and concluded that constructivist learning did not modify the starting idea that Swedish students had about the concept, although the signs of resistance to accept a specific theory about it could be productive in terms of learning.

It becomes necessary at this point to highlight the attacks which are being suffered by constructivism as a learning mode closely linked to the reviled 'new pedagogy,' which -in the opinion of its critics- chooses to liberate classrooms from content transmission, focusing on the idea of 'learning to learn' and on the constant 'promotion of autonomy.' Inger Enkvist criticizes the fact that this new pedagogy -that she revilesplaces emphasis on the "continuous promotion for the expression of the student's personality" instead of emphasizing the contents of the subjects included in the curriculum (Enkvist, 2012, p. 19). That pedagogy launched constructivism as a learning theory which -in this author's opinion- has had visible failures: "Schools were created with the aim of helping students learn what society had decided to establish as worth learning but, what is the purpose of a school if students decide what they want to learn?." In the context of traditional pedagogy, the teacher imparted contents to the student; instead, the new pedagogy turns the teacher into a mere facilitator and the student no longer learns a subject but learns to learn (Enkvist, 2012, p. 38). It seems that Inger Enkvist is trying to make a new substitution in the main actors of the teaching-learning process; the syllabus and the teacher should recover the central place that the new pedagogy gave to the student and to self-learning. What cannot be subject to interpretation is her mention of the Fölster report for Sweden (2009), which conceives the school as an organization dedicated to knowledge production and which recommends "opening the possibility of an independent but State-financed teacher training" (Enkvist, 2012, pp. 42 and 48), an idea that will be found again later on.

Perhaps one of the factors which could increase both the conceptual deficits and the abstraction of PE as a subject is the lack of epistemological approaches, which have been recognized to have a 'singular relevance' for PE (Jiménez, Jiménez \& Palmero, 2006, p. 265). Some scholars even denounce the 'absence' of such positionings in PE research, which undermines not only the methodological foundation of the research process but also the ethical coherence of the researcher who tries to appear "as neutral and independent from the social and cultural reality" without having carried out an epistemological reflection (Tello, 2012, pp. 53 and 55). This becomes especially important in our discipline which, the same as any other science -but particularly in its case- could be politicized from the actual research and afterwards, in its dissemination. An example of this is shown by Henig (2009) in his study about the so-called 'charter' schools. Hence the need for an ethical reflection on PE from positions which make clear the principles or values justifying our analysis or the extent to which our work can be detrimental to others or legitimize wrong policies or power relationships (Gewirtz, 2007). Nevertheless, this reflection seems to be absent in many research works. The analysis of several journals leads Tello and Mainardes (2011) to reach this conclusion with regard to Latin America, where, in their opinion, it is hard to find any research on PE which follows an epistemological perspective in the strict sense of the term, when choosing one epistemological perspective or another implies assuming an ethical commitment as well as providing the research with coherence. Not only this; epistemological analysis makes it possible to relate interpretations, procedures and forms of government, curricular aspects, governance issues, the roles played by the competing actors (States, politicians, institutional and student leaders, researchers and intellectuals, consultants and entrepreneurs...), whose relationships are determined by the interests in which they become involved, by the alliances that they create, by the regimes that they introduce. Linking these three types of knowledge -'knowledge interest,' 'knowledge alliances,' and 'knowledge regimes'- (Bleiklie \& Byrkjeflot, 2002, p. 528) makes it possible to have a better understanding not only about the development, complexity and ambiguity of $\mathrm{PE}$ but also about teaching reforms, documents referring to national policies, and technical and administrative plans, as well as about the situation of the individuals involved in educational practice (Aasen, Prøitz \& Sandberg, 2013).

\section{PROBLEMS AND CHALLENGES FOR THE POLITICS OF EDUCATION AS A GOVERNMENT IDEA AND ACTION}

As a government action, PE presents more serious problems than those mentioned above, since they directly affect equality and social cohesion. Both of them suffer with the market dynamics that is currently colonizing PE. Neoclassical-style economics acts upon them as a new imperialistic system (Allais, 2012) that forces them to use tools which are typical of neoclassical economics -product determination according to supply and demand; competition; expenditure rationalization based on business performance; consumer primacy...- and new strategies which are sometimes distant from the traditional formative goals of PE. One of them, mentioned by Gillies (2011) is the bet made through the entrepreneurial discourse on 'agility' as a response to the ever-changing markets, to the detriment of 'flexibility' which had represented a desirable educational purpose until not long ago. According to this approach, an 'agile' -more dynamic and practical- individual is in a better position to maintain his economic value in a globalized world with markets under vertiginous transformation. This conception is beginning to take hold in the educational discourse. Gillies claims that 'agility' is aligned with the neoliberal concept of 'self-entrepreneurship' and also with the new 'government turn' thanks to which the political aims are achieved by means of apparently autonomous actions, supposedly due to individuals' responsibility and initiative -when, in fact, these actions are guided by control mechanisms alien to those individuals.

This system actually appears with an apparel characterized as 'anti-elitist' -both worth and merit will be taken into account-, 'progressive' -it is supposed to break up with policies of the past- and respectful with every individual, on whom it places stress valuing their responsibility and self-esteem and whom we try to convince that the reforms derived from neoliberal policies will turn them into almighty actors freed from the bureaucratic restrictions imposed by governments. However, these 'ideological fantasies of empowerment' hide the subordination of actors -parents, teachers- to such neoliberal rationales (Wright, 2012); and the promise of 'partnership' within a context of entrepreneurial logic is just rhetoric which conceals plans to privatize public education (Ball, 2009). And not only plans but also practices; Au and Apple detected such scheming 
in the 'No Child Left Behind Act of 2001' which, despite having been born as an ideological compromise between the US 'left' and 'right,' in practice forms part of a conservative political movement that imposed a rigid accountability system at public schools, generating an enormous volume of failure. And that failure was subsequently used as part of a broader project that includes neoliberal educational reforms oriented to free market and the privatization of education (Au \& Apple, 2010, p. 421).

In this context, PE is driven to modify the prominence of actors and to adopt mechanisms which are typical of neoclassical economics. The State is perhaps the educational actor that has suffered the deepest transformation. The movement of power centers towards supra- and sub-national levels as well as the gradual introduction of neoliberal thinking has changed the State's traditional educational role. The recontextualization of the nation and the new forms of government or deregulation as a new requirement for equality draw a lowintensity State profile. The emergence of supranational government structures -not to mention those inherent to decentralized regimes- forces States to play a merely collaborative or even a 'copycat' role that basically consists in following the policies dictated there-even though the State itself is sometimes involved in those structures. To quote just one example, the so-called 'Bologna process' is not only a reform of higher education but also a paradigmatic political phenomenon that entails the dissolution both of national approaches to PE and of the new forms of international governance.

However, the most remarkable transformation stems from its conversion into a managerial State. This means abandoning (a) the welfare state model and, consequently, the elimination of boundaries between the public and private spheres; (b) the establishment of new relationships between civil society and the State; and (c) new ways of assessing public policies. All this affects the educational policies to which the entrepreneurial rationale is being transferred (Gomes \& Gandin, 2012). In fact, the State's concern for education in the last few decades has focused on efficiency, giving priority to calculations over any other aspect. According to Óscar Espinoza (2008), this has resulted in the predominance of policies which increase control and power to the detriment of participation and equality -these being tensions before which the State will only act as a counterbalance, because the possibility of resolving them is clearly beyond its reach. The change of primacy in the actors becomes evident: the market conquers the prominence once exerted by the State; economics assumes the main role previously played by politics, the manager that of the professional, business effectiveness that of social cohesion, the individual that of the collectivity... Accountability, school governance, teaching assessment or financing and schooling are some of the areas affected by this change of main characters.

The accountability policy (hereinafter, AP) - which is part of a wider trend, managerialism- generates conflicting positions. Some see it as the most perfect solution for assessment: it allows for a "more exact diagnosis and a more accurate intervention at all levels, taking the resources wherever they are needed but establishing compromises", while simultaneously "giving autonomy and responsibility back to educational centers" (Sierra, 2006, p. 473). Furthermore, it results from the "he who pays is in charge' logic and therefore has legitimacy to demand accountability for the resources utilized. For others, AP is an ideological discourse which emphasizes equal opportunities in education, its equality and efficiency. It is spread by means of a 'sacred language' which disseminates neoliberal values and places the manager and the market in the place where the professional used to be. Tatiana Suspitsyna (2010) also describes AP as a 'technology of governmentality' which imposes the opening of educational institutions to governmental supervision. This seems to be deduced, for example, from the study by Lewis and Young, where it is argued that the lack of agreement in the USA on the best teacher training that could render education more effective led them to focus their attention on students' results as an indicator of teachers' quality -there are even systems which evaluate them according to the overall degree of success achieved by students. They warn that this approach has been used to hold teachers responsible for school system effectiveness and, consequently, to consolidate the accountability system on the basis of the results obtained in that way (Lewis \& Young, 2013, pp. 190-194). Some people think that these initiatives respond to political reasons rather than to a real interest in improving teacher training, and more precisely to a search for the deregulation of teacher training with the aim of dismantling the institutions devoted to the training of teachers and breaking the monopoly of their training. In the view of Lewis and Young, teachers' accountability has reached an 'agenda' status, thus reinforcing the idea that it is necessary to demand some kind of responsibility. In fact, this language makes it impossible to resist a mechanism which uses its discourse to demand responsibility (accountability) and encourages the allocation of resources to monitor that responsibility from the federal government as well (Lewis \& Young, 2013, pp. 212213).

The dissenting reasons include the opinion according to which market-centered AP not only has failed to confirm the effects that it promises (Au \& Apple, 2010, Musoba, 2011) but also stands very few chances of achieving its stated goals, especially equal opportunities for students belonging to minorities and lowincome groups (Suspitsyna, 2010). What is more, AP has been refuted by numerous teachers because, being based on instruction results, it ignores the fact that the strongest influences on school performance are more often found outside the school than inside it (Angus, 2012). Not only this; APs have other consequences which make them become the object of criticism and opposition: together with policies such as freedom of choice, they have provoked the proliferation of regulations, the creation of new structures and the enlargement of other already existing ones, and the appearance of unprecedented coalitions and strategies between interest groups, all of which adds a high degree of complexity to AP. McDonnell (2013) argues that this complexity is not accompanied by the corresponding governance structures, especially at a local level, which in turn facilitates an increased centralization of educational policy through an extension of the State's influence particularly on school districts. Governments' inability to carry out an effective management of APs has additionally led to increase the number of political actors who hinder educational system self-government. A number of studies (DiMartino \& Scott, 2013, Anagnostopoulos, Rutledge \& Bali, 2013) have shown how difficult it is for governments to handle the conflicting interests of private stakeholders. McDonnell (2013) has also checked how APs are provoking a realignment of political and economic coalitions as well as tensions between unions. In turn, teachers and their unions see that APs reduce their professional autonomy and capacity to influence the educational policy in which they believe their experience could prove highly valuable. No wonder teaching professionals resist APs understood like this and unions demand more cooperation and an improved teacher training 
within this context of new school governance (Jacoby, 2011). However, because of their opposition to this policy, they are often accused of placing their own interests before the success of reforms meant to improve students' results.

The growth of APs has other significant effects: their demands can only be met through more private sector contracting and a subsequent reduction of the role played by the public sector in decision-making processes, which places the former in a situation of power that sometimes makes it difficult to force that private sector to be made accountable for its own management (DiMartino, 2013). Furthermore, this scenario provokes alterations in power structures which can even end up eliminating traditional forms of democratic government (Arsen \& Mason, 2013). If the presence of the public sector and its capacity to express opinions and vote are necessary to maintain the public education system, then AP represents a threat for that support (Trujillo, 2013 \& Arsen \& Mason, 2013). The inescapable challenge for $\mathrm{PE}$ is therefore to harmonize efficiency and democracy at school, and to keep a balance between the high politics where big decisions are made and the teacher's school practice where those decisions are implemented (Berry \& Herrington, 2013). Unless those adjustments can be achieved, students are likely to become the great losers, above all those who have been placed in a disadvantageous position by the neoliberal education system; they especially deserve to be treated in a more decent, committed and respectful way than what is done by the accountability ideology and the top-down approach which prevails in school managerialism (Angus, 2012).

The scope of AP effects is even greater. As highlighted by Pedró, they have generated a governance model for educational systems and schools inspired by the conception of education as a product subject to market mechanics where the 'users' of the educational system are 'consumers' of a product -educationwhich they can choose depending on its quality. This paradigm differs from the governance of educational systems supported on the conception of education as a public service which, despite being submitted to assessment too, does not incite to "wild competitiveness between schools on the basis of the results obtained by students," considering also the means and not only the results (Pedró, 1993, pp. 82-83). Indeed, the concern for effectiveness has led to conceive school reforms focused on the governance of educational centers taking their autonomy and responsibility as reform axes. However, despite being undoubtedly important for school governance (Allen \& Mintron, 2010), they both lose interest if they serve as arguments to strengthen the control over schools and if they are uncritically used without questioning the consequences that the establishment of effectiveness goals and APs may have. After all, some people think that the introduction of this new managerial culture may be due to reasons other than effectiveness; the scarce significance of the results obtained by the new ways to manage educational centers as companies, in socioeconomic and cultural terms and with regard to student performance, leads Merchán (2012) to wonder -for the Spanish case, but with the possibility of extrapolating his reflection to others- if the introduction of this new culture actually responds to reasons other than those stated above.

If the Accountability Policy has altered the Politics of Education (Jacobsen \& Young, 2013), exactly the same can be said about what is a product of the former: the new ways to assess the results obtained by students. As shown on the preceding pages, educational assessment affects the whole school institution; nevertheless, this paper will only refer to something which many scholars see as a serious problem of PE: its governance by numbers.

The utilization of databases to administer educational systems and formulate educational policies appeared in the second half of the 19th century and developed throughout the 20th century (Borer \& Lawn, 2013, Nóvoa, 2013). However, comparison by numbers is currently becoming a governance instrument, a new form of power which designs PE on the basis of the 'evidence' provided by figures. Indeed, the 'Programme for International Student Assessment' (PISA) launched in the late 1990s -which seeks to assess student training at the end of the compulsory teaching stage- has become an indirect but influential tool of the new political technology applied to govern the European educational space by numbers (Grek, 2009). PISA is not only an instrument which measures knowledge; in fact, it generates knowledge (Carvalho, 2009). As a knowledge measuring tool, it creates a new type of knowledge which prevails appearing as a mechanism meant to describe 'reality' and define the achievements that a country must obtain for its education to be considered 'adequate.' If it manages to achieve a 'satisfactory' change in the indicators suggested, the country in question will be able to position itself on a global level. According to Carvalho, PISA is consequently seen as a means for the construction of a supranational political regulation space which defines the educational 'reality', suggests the 'suitable' approaches to its governance and produces knowledge for politics. Thus, PISA -i.e. numbers- becomes an instrument for the governance of educational systems. Barroso and Carvalho do not believe that PISA - that is to say, the OECD- depends on the data created by the national education systems; instead, it determines the issues that need to be covered through its enquiry; in this sense, PISA "generates its own data." In the view of these two Portuguese professors, PISA contains a series of specifications and characteristics which permit to show its "politicization" and the fact that it is a mechanism which "guarantees that the financial systems will have control over the priorities in the program and over its application." Therefore, PISA can be seen as a "knowledge-based regulation instrument" which creates "interpretations and normative models for actions on the educational reality." Its results as well as the methodology used "induce changes in the regulation forms and help governments find new legitimization mechanisms." And, since the increasingly relevant competitiveness discourse requires comparison to be situated in the market, PISA introduces "comparative logic as a way to administer governance" creating the need for permanent comparison with others if one wants to be assessed and placed in competitiveness rankings (Barroso \& Carvalho, 2008, pp. 77-78).

For some scholars, the consequences of such an assessment are the relegation of political and ideological approaches (Nóvoa, 2013); a way to legitimize certain decisions, to technify and depoliticize public action (Fernandes, 2011, p. 283); and a chance not only for the education to be governed by international organizations but also for the consolidation of a "global thinking" system meant to guide educational policies, identifying the problems of education and saying how they should be exposed and dealt with (Barroso \& Carvalho, 2008). For others, though, these ways to monitor and compare results are changing the essence of teaching and what it means to teach; they are altering the ways in which teachers plan what they do as 
well as the relationship with their colleagues and students; and they are destroying sociability and collectivity, which have been replaced by a new repertoire of deformed emotions (resulting from a consciousness divided between beliefs and expectations) and social relationships, insofar as individuals are valued by what they produce rather than by what they are (Ball, 2012).

Despite this criticism, the impact of PISA -and, therefore, of the OECD- is becoming increasingly significant in all countries, even in those which, like France, not only have expressed a certain degree of aversion to international comparisons and have had a difficult relationship with the OECD but made equality one of the guiding principles for their educational policy and are now focusing their efforts on emulating the 'recent PISA champion': Finland (Dobbins \& Martens, 2012).

The need for countries to use comparison in order to show the competence of their education and become positioned in the market is also felt by the schools governed through the principles of neoclassical economics. Apart from resorting to new forms of governance, they implement a questionable student admission system fed by the AP that they follow. Regardless from the fact that the free choice of school (hereinafter, FCS) has supporters and opponents, what matters is that it has become a source of concern for families and governments in many countries. The reason undoubtedly lies in the fact that the education of the new generations is of immense significance for both those generations and those countries. This does not mean, however, that the results derived from FCS respond to the goals stated for its defense. This is actually an issue which still takes up many pages in the specialized press.

As is well known, it all stems from the starting premise according to which FCS will encourage competition between teaching establishments, which will be forced to offer the best possible education if they want to be selected. It is understood that free competition will cause an optimization of the system and its constant renovation, which in turn benefits individuals selecting a school; after all, its survival is going to depend on their choice. Nevertheless, numerous studies have shown the scarce impact that FCS policies have on teaching quality (Rambla, 2003, Lubienski, Weitzel \& Lubienski, 2009, Bunar, 2010). The assumption that the centers which do not meet the demands of their potential customers will close their doors has proved wrong as well: they remain open to receive those who reject the most selective schools (Duru-Bellat, 2004). Even the argument that such freedom allows parents to assume their election duty committing themselves to the discourses of community responsibility and ethnic diversity and leaving aside individualism and selfish interest has been refuted. In this respect, Wilkins (2010) proved that mothers make their decisions on the choice of a school contradictorily, with reasons related to individual and collective aspects, to political and economic considerations, to the public and private spheres, or to their condition as citizens or consumers -all of which leads this author to question the citizen/consumer and community/individual models as explanatory of school choices.

What is the most visible result of FCE then? In fact, it is school segregation. Numerous studies conclude that FCS is an instrument that favors segregation, even regardless of the economy-based reasons which are behind it. Coldron, Cripps and Shipton (2010) study how and why segregation takes place in English secondary schools and reach the conclusion that the children of families with similar characteristics regarding wealth, education and social class tend to be brought up together, away from the social groups that are more distant from them. Social membership triggers a conscious decision by most of both groups -the more and less socially privileged- to choose segregated education. For these authors, it is parents' practices and not so much the effects caused by the commoditization of education that lead to school segregation. This self-segregation also occurs from a racial point of view, as shown by García (2012) in a study about the impact of school choice decisions based on the racial composition of students coming from district schools (controlled by the federal or local government) who choose 'Charter Schools' -free public schools that operate autonomously- which apply race-based segregation to a greater extent than district schools.

Of course, social status, the educational level of choicemakers, the action of lobbies that defend private dependent schools, as well as micro-politics and its strategies, are factors which can favor a segregating choice, as has been studied for the Spanish and Chilean cases by Rambla, Valiente and Frías (2011), where fifteen-year-old students present a significant degree of segregation.

A large number of works have shown that the assumptions and arguments provided to defend FCS are either wrong or fail to show a solid connection with the results obtained (FernándezSoria, 2007). These research studies additionally highlighted the negative consequences that an absolute application of FCS can entail with regard to equality and social cohesion: risk of inequalities, segregation and social reproduction, depoliticization, a power balance modification in the educational system and a threat for education as a public service. The unrestricted application of FCS would encourage centers to select their students according to their advantageous potential for school performance.

This could suggest that private education is per se more successful than public education when, in fact, it is well known that the differences in school success between private and public centers are explained amongst other reasons, though especially, by the different social composition of private schools (Dronkers \& Robert, 2008). However, Arreman and Holm (2011) concluded in their analysis of the Swedish case that there is a market discourse which implies breaking with the existing social and public education policies. This discourse is luckily being confronted through critical attitudes that demand greater control over the so-called 'independent schools' and more attention to a commoditized education which always pays more attention to financial profit than to pedagogy and to the success of the student-citizen. The involvement of educational companies in a wide range of public education services, also through strategies such as partnership (Ball, 2009), makes us think of the challenges faced by public education if it wants to avoid what so far looks like a gradual privatization. There is actually no doubt about it: the privatization of public education has been one of the most worrying problems affecting PE for a few decades now.

\section{CONCLUSIONS}

As a subject, the specialized academic media show a visible concern for PE teaching. They stress the need to use active methods in the teaching-learning process with a greater prominence of students. Learning simulations and problembased teaching are some of the procedures to achieve it. Their use improves students' understanding, motivation and attitude toward the subject and increases their civic competence as well as their interest in local and global political affairs. However, these recommendations contradict the offensive that the so- 
called 'new pedagogy' launches against student-centered teaching and its role as a builder of student learning and which, the same as in classical pedagogy, seems to be trying to give the prominence in the teaching-learning process back to the teacher. In this case, one could wonder how much room is left within this framework to student autonomy and to the critical thinking that can challenge the existing order where necessary.

The teaching-learning process of Political Science in general and the Politics of Education in particular- comes up against problems which teachers and researchers have the challenge to overcome. The most urgent one consists in rescuing young people from political apathy and making them feel the need for democratic participation. The link established between a good teaching of political science and civic education leads to demand measures which improve the former: removing the separation between teaching and research and increasing the connection between teachers of this subject to favor the intercommunication of their activity in the classrooms. This relationship becomes even more necessary in a discipline like this one, which presents conceptual and epistemological difficulties. Reaching a consensus on the meaning of some key teaching and research concepts and reflecting on the epistemological approaches on which our subject is supported -or on their absence- are only two of the requirements needed for a suitable development of this knowledge field.

As a government action, PE shows more significant problems and challenges which directly affect equality and civic cohesion. The submission of PE to the rules of neoclassical economics weakens the foundations of those two values. One of the effects caused by that submission is the rise of the market and the degradation of the State as the traditional privileged actor of politics -and the consequent reduction of its inequalitycompensation role. The conversion of the welfare State into a managerial State is a clear symptom of the success in achieving a 'minimum' State where efficiency must prevail over social cohesion. The introduction of new policies for accountability, school governance, teaching assessment and schooling tend to prioritize the change of main actors in PE: the market instead of the State, economics instead of Politics, international policies instead of state and national ones, the manager instead of the professional, the individual instead of the collectivity, and freedom instead of equality. AP is contributing to centralize political action, to reduce the intervention capacity stemming from teachers' professionalism, to favor the presence of the private sphere to the detriment of the public sphere, and to undermine the democratic decision-making processes. The challenge for PE consists in harmonizing efficiency and democracy at school; in coordinating international and national policies; in finding a balance between macro- and micro-politics, and in examining and making known to everyone which actors help give more cohesion to society.

Another challenge lies in adopting the new educational assessment tools, but without allowing numbers -or assessment technification - to become the new PE governance models, to relegate ideology and politics, and to modify the essence of teaching and what it means to teach. After all, assessment by numbers, the same as AP, prefers to ignore that school success depends more on out-of-school influences than on those exerted from inside the school. That is also why FCS policies -another serious problem in $\mathrm{PE}-$ do not bring the positive effects announced by their supporters, segregation being one of its aspects which raises more interest in academic studies, and more agreement on its causes. This consensus equally spreads to a large part of its consequences: risk of inequalities, segregation and social reproduction, a power balance modification in the educational system and a threat for education as a public service.

The problems mentioned so far seem to mark a gradual privatization of education as a public service. In fact, there is undoubtedly an important strand of opinion according to which the authorities should deregulate public education, break all links between politics and pedagogy, and rethink what kind of service education is and who must deliver it, or what is the role of subsidiarity in the educational field (Martínez \& Seguí, 2011, p. 11).

It was said at the beginning of this paper that what has been described as PE problems are actually seen by others as solutions for our present-day education; and that the different views about those problems depended on how politics was conceived. Starting from our previous conception of politics, the turns in PE which have been described in this paper affect the economic domain (the private sphere) to a greater extent than the political domain (the public sphere); they have more to do with the idea of freedom than with that of equality; they favor the development and improvement of individuality rather than that of the community. Those which have been described here as PE problems can only become transforming instruments for the benefit of the common good -this being the main challenge faced by $\mathrm{PE}$ - if they satisfactorily meet the demands for the social cohesion level that a democratic society needs. If educational policies -AP, FCS...- fail to promote social cohesion and become installed in the social imagery as valid and positive, then the problem does not only affect PE, but also society as a whole.

\section{REFERENCES}

Aasen, P., Prøitz, T. S., \& Sandberg, N. (February, 2013). Knowledge Regimes and Contradictions in Education Reforms. Educational Policy. doi: 10.1177/0895904813475710.

Allais, S. (2012). 'Economics imperialism', education policy and educational theory. Journal of Education Policy, 27(2), 253-274. doi: 10.1080/02680939.2011.602428.

Allen, A. \& Mintrom, M. (2010). Responsibility and School Governance. Educational Policy, 24(3), 439-464. doi: 10.1177/0895904808330172.

Anagnostopoulos, D., Rutledge, S., \& Bali, V. (2013). State Education Agencies, Information Systems, and the Expansion of State Power in the Era of Test-Based Accountability. Educational Policy, 27(2), 217-247. doi:10.1177/0895904813475713.

Angus, L. (2012). Teaching within and against the circle of privilege: reforming teachers, reforming schools. Journal of Education Policy, 27(2), 231-251. doi: 10.1080/02680939.2011.598240.

Arreman, I. E. \& Holm, A. S. (2011). Privatisation of public education? The emergence of independent upper secondary schools in Sweden. Journal of Education Policy, 26(2), 225-243. doi: 10.1080/02680939.2010.502701.

Arsen, D. \& Mason, M. L. (2013). Seeking Accountability Through State-Appointed Emergency District Management. Educational Policy. 27(2), 248-278, doi:10.1177/0895904813475711.

Au, W. \& Apple, M. W. (2010). Testing, Accountability and the Politics of Education. Educational Policy, 24(2), 421-433. doi: 10.1177/0895904810361724.

Ball, S. J. (2009). Privatising education, privatising education policy, privatising educational research: network governance and the 'competition state'. Journal of Education Policy, 24(1), 83-99. doi: 10.1080/02680930802419474.

Ball, S. J. (2012). Reforma educacional como barbárie social: economismo e o fim da autenticidade. Práxis Educativa, 7(1), 33-52. doi:10.5212/PraxEduc.v.7i1.0002.

Baranowski, M. \& Weir, K. (2010). Power and Politics in the Classroom: The Effect of Student Roles in Simulations. Journal of Politi- 
cal Science Education,

$6(3)$

217-226.

doi:

10.1080/15512169.2010.494465.

Barroso, J. \& Carvalho, L. M. (2008). PISA: un instrument de régulation pour relier des mondes. Revue française de pédagogie, 164(3), 7880

Bernstein, J. L. (2008). Cultivating Civic Competence: Simulations and Skill-Building in an Introductory Government Class. Journal of Political Science Education, 4(1), 1-20. doi: 10.1080/15512160701815996.

Berry, K. S. \& Herrington, C. D. (2013). Tensions Across Federalism, Localism, and Professional Autonomy: Social Media and Stakeholder Response to Increased Accountability. Educational Policy, 27(2), 390-409. doi:10.1177/0895904812466171.

Bleiklie, I. \& Byrkjeflot, H. (2002). Changing Knowledge regimes: Universities in a new research environnement. Higher Education, 44 519-532. doi: 10.1023/A:1019898407492

Borer, V. L. \& Lawn, M. (2013). Governing Education Systems by Shaping Data: from the past to the present, from national to international perspectives. European Educational Research Journal, 12(1), 48-52. doi: 10.2304/eerj.2013.12.1.48.

Bostock, W. (2011).The Role of Film in Teaching Political Science: 5 Fingers and Operation. Journal of Political Science Education, 7(4), 454-463. doi: 10.1080/15512169.2011.590067.

Brunell, L. A. (2013). Building Global Citizenship: Engaging Global Issues, Practicing Civic Skills. Journal of Political Science Education, 9(1), 16-33 doi: 10.1080/15512169.2013.747833.

Bunar, N. (2010). Choosing for quality or inequality: current perspectives on the implementation of school choice policy in Sweden. Journal of Education Policy, 25(1), 1-18. doi:10.1080/02680930903377415.

Carvalho, L. M. (2009). Governando a educação pelo espelho do perito: uma análise do PISA como instrumento de regulação. Educaçâo e Sociedade, 30(109), 1009-1036. doi: 10.1590/S010173302009000400005

Coldron' J., Cripps, C., \& Shipton, L. (2010). Why are English secondary schools socially segregated? Journal of Education Policy, 25(1), 19-35. doi: 10.1080/02680930903314285

Curtis, S. \& Blair, A. (2010). Experiencing Politics in Action: Widening Participation in Placement Learning and Politics as a Vocation. Journal of Political Science Education, 6(4), 369-390. doi:10.1080/15512169.2010.518093.

DiMartino, C. \& Scott, J. (2013). Private Sector Contracting and Democratic Accountability. Educational Policy, 27(2), 307-333. doi: $10.1177 / 0895904812465117$.

Dobbins, M. \& Martins, K. (2012). Towards an education approach à la finlandaise? French education policy after PISA. Journal of Education Policy, 27(1), 23-43. doi: 10.1080/02680939.2011.622413.

Dronkers, I. \& Robert, P. (2008). Differences in Scholastic Achievement of Public, Private Government-Dependent, and Private Independent Schools. A Cross-National Analysis. Educational Policy, 22(4), 541577. doi: 10.1177/0895904807307065.

Duru-Bellat, M. (2004). Debate y prácticas en materia de elección de centros escolares en los países europeos y en los Estados Unidos. Revista de Educación, 333, 41-58.

Enkvist, I. (2011). La buena y la mala educación. Ejemplos internacionales. Madrid: Encuentro.

Espinoza, Ó. (2008). La relación Estado-educación y el proceso de reforma educacional: una aproximación desde la teoría crítica. Revista Iberoamericana de Educación, 45(1), 1-13. Retrieved from: http://www.rieoei.org/deloslectores/2106Espinoza.pdf

Ferman, B. (2012). Educating for Democracy: Reflections From a Work in Progress. Journal of Political Science Education, 8(3), 231-250. doi: 10.1080/15512169.2012.695966.

Fernandes, E. (2011). O 'Programme for International Student Assessment' (PISA) como instrumento de regulação das políticas educativas. Doutoramento em Educação. Especialidade: Administração e Política educacional. Universidade de Lisboa. Instituto de Educação. T. I.

Fernández-Soria, J. M. (2007). Igualdad y libertad de elección de centro docente: una cuestión polémica para un acuerdo necesario. Revista de Educación, 344, 41-59.

Fernández-Soria, J. M. (2012). La reforma de la Universidad y el declive de la política. In Homenaje a Ángel González Hernández (pp. 109137). Murcia: Universidad de Murcia.

Ferry, J. M. (1998). El nuevo espacio público. Barcelona: Gedisa.

Fölster, S. et al. (2009). Den orättvisa skolan. Estocolmo: Hjalmarsson \& Högberg.
García, D. R. (2008). The Impact of School Choice on Racial Segregation in Charter Schools. Educational Policy, 22(6), 805-829. doi: $10.1177 / 0895904807310043$.

Gershtenson, J., Rainey Jr., G. W. \& Rainey, J. G. (2010). Creating Better Citizens? Effects of a Model Citizens' Assembly on Student Political Attitudes and Behavior. Journal of Political Science Education, 6(2), 95-116. doi: 10.1080/15512161003708129.

Gewirtz, Sh. (2007). A reflexividade ética na análise de políticas: conceituaçao e importancia. Praxis Educativa, 2(1), 7-12.

Gillies, D. (2011). Agile bodies: a new imperative in neoliberal governance. Journal of Education Policy, 26(2), 207-223. doi: 10.1080/02680939.2010.508177.

Gomes de Lima, I. \& Gandin, L. A. (2012). Entendendo o estado gerencial e sua relaçâo como a educaçâo: algunas ferramentas de análise. Práxis Educativa, 7(1), 69.84. doi: 10.5212/PraxEduc.v.7i1.0004.

Grek, S. (2009). Governing by numbers: the PISA 'effect' in Europe. Journal of Education Policy, 24(1), 23-37. doi: $10.1080 / 02680930802412669$.

Hartlaub, S. G. \& Lancaster, F. A. (2008). Teacher Characteristics and Pedagogy in Political Science. Journal of Political Science Education, 4(4), 377-393. doi: 10.1080/15512160802413741.

Henig, J. R. (2009). Politicization of Evidence. Lessons for an Informed Democracy. Educational Policy, 23(1), 137-160. doi: $10.1177 / 0895904808328525$.

Huerta, J.C. \& Jozwiak, J. (2008). Developing Civic Engagement in General Education Political Science. Journal of Political Science Education, 4(1), 42-60. doi: 10.1080/15512160701816101.

Jacobsen, R. \& Young, T. V. (2013). The New Politics of Accountability: Research in Retrospect and Prospect. Educational Policy, 27(2), 155-169, doi:10.1177/0895904813478164.

Jacoby, D. (2011). Teacher Unionization in School Governance. Educational Policy, 25(5), 762-783. doi: 10.1177/0895904810374852.

Jansson, M., Wendt, M., \& Ase, C. (2013). Common-Sense Notions of "Nation": A Challenge for Teaching. Journal of Political Science Education, 9(1), 34-51. doi: 10.1080/15512169.2013.747837.

Jiménez, A., Jiménez, J., \& Palmero, C. (2006). La política educativa y la naturaleza compleja de la educación. Nuevos enfoques epistemológicos. Revista Española de Pedagogía, LXIV(234), 249-272.

Jones, T. (2013). Understanding Education Policy. Springer. doi: 10.1007/978-94-007-6265-7.

Lewis, W. D. \& Young, T. V. (2013). The Politics of Accountability: Teacher Education Policy. Educational Policy, 27(2), 190-216. doi: 10.1177/0895904812472725.

Lubienski, C., Weitzel, P., \& Lubienski, S. Th. (2009). Is There a "Consensus" on School Choice and Achievement? Advocacy Research and the Emerging Political Economy of Knowledge Production. Educational Policy, 23(1), 161-193. doi: $10.1177 / 0895904808328532$.

Martínez, J. \& Seguí, Ll. (2011). Introducción. In Enkvist, I. La buena y la mala educación. Ejemplos internacionales (pp. 9-15). Madrid: Encuentro.

McDonnell, L. (2013). Educational Accountability and Policy Feedback. Educational Policy, 27(2), 170-189. doi:10.1177/0895904812465119.

Merchán Iglesias, J. (2012). La introducción en España de la política educativa basada en la gestión empresarial de la escuela: el caso de Andalucía. Archivos Analiticos de Políticas Educativas, 20(32), 124, Retrieved from http://epaa.asu.edu/ojs/article/view/1059

Musoba, G. M. (2011). Accountability Policies and Readiness for College for Diverse Students. Educational Policy, 25(3), 451-487. doi: $10.1177 / 0895904810361721$.

Nóvoa, A. (2013). Numbers Do Not Replace Thinking. European Educational Research Journal, 12(1), 139-148. doi:10.2304/eerj.2013.12.1.139.

Pedró, F. (1993). Estado y Educación en Europa y los Estados Unidos: situación actual y tendencias de futuro. Revista Iberoamericana de Educación, 1, 59-93.

Perry, L. B. (2009). Conceptualizing Education Policy in Democratic Societies. Educational Policy, 23(3), 423-450. doi:10.1177/0895904807310032.

Puelles Benítez, M. (2006). Problemas actuales de politica educativa. Madrid: Morata.

Rambla, X. (2003). Las desigualdades de clase en la elección escolar. Revista de Educación, 330, 83-98.

Rambla, X., Valiente, Ó., \& Frías, C. (2011). The politics of school choice in two countries with large private-dependent sectors (Spain and Chile): family strategies, collective action and lobbying. Journal 
of Education Policy, 26(3), 431-447. doi:10.1080/02680939.2010.540675.

Sierra Orrantia, J. (2006). Los retos de la evaluación de los sistemas educativos. Revista de Educación, $N^{\circ}$ extraordinario, 457-474.

Sloam, J. (2010). Introduction: Youth, Citizenship, and Political Science Education: Questions for the Discipline. Journal of Political Science Education, 6(4), 325-335. doi: 10.1080/15512169.2010.518085.

Suspitsyna, T. (2010). Accountability in American education as a rhetoric and a technology of governmentality. Journal of Education Policy, 25(5), 567-586. doi: 10.1080/02680930903548411.

Tello, C. G. (2012). Las epistemologías de la política educativa: vigilancia y posicionamiento epistemológico del investigador en política educativa. Práxis Educativa, 7(1), 53-68. doi: 10.5212/PraxEduc.v.7i1.0003.

Tello, C. \& Mainardes, J. (2011). La posición epistemológica de los investigadores en Política Educativa: Debates teóricos en torno a las perspectivas neo-marxista, pluralista y pos-estructuralista. Archivos analiticos de políticas educativas, 20(9), 1-30. Retrieved from http://epaa.asu.edu/ojs/article/view/988

Teten, R. L. (2010). When in Rome, Do as Jon Stewart Does: Using America: The Book as a Textbook for Introductory-Level Classes in American Politics. Journal of Political Science Education, 6(2), 163187. doi: $10.1080 / 15512161003708335$.

Thornton, S. (2010). From "Scuba Diving" to "Jet Skiing"? Information Behavior, Political Science, and the Google Generation. Journal of Political Science Education, 6(4), 353-368. doi: 10.1080/15512169.2010.518111.

Trujillo, T. M. (2013). The Disproportionate Erosion of Local Control: Urban School Boards, High-Stakes Accountability, and Democracy. Educational Policy, 27(2), 334-359. doi:10.1177/0895904812465118.

Wilkins, A. (2010). Citizens and/or consumers: mutations in the construction of concepts and practices of school choice. Journal of Education Policy, 25(2), 171-189. doi: 10.1080/02680930903447671

Williamson, J. \& Gregory, A. S. (2010). Problem-Based Learning in Introductory American Politics Classes. Journal of Political Science Education, 6(3), 274-296. doi: 10.1080/15512169.2010.494485.

Wright, A. (2012). Fantasies of empowerment: mapping neoliberal discourse in the coalition government's schools policy. Journal of Education Policy, 27(3), 279-294. doi: 10.1080/02680939.2011.607516.

\section{ACKNOWLEDGMENT}

This article is framed within the research activities of the Unit for Research in Politics of Education (UINPE) of the Department of Comparative Education and History of Education of the University of Valencia. 